\title{
INSTITUTIONAL ASSUMPTIONS OF COMPETITION POLICY EFFICIENCY
}

\author{
Boban Stojanovic*, Vladimir Radivojevic, Tanja Stanisic \\ Faculty of Economics, University of Nis, Nis, Serbia
}

\begin{abstract}
An adequate normative regulation isa prerequisite for a successful implementation of the competition policy as a fundament of a market economy is. With current legal solutions in the field of the competition policy, Serbia has provided the necessary institutional framework for the efficient functioning of the market and the establishment of effective competition on it. The effectiveness of this framework is necessary to evaluate through a market analysis, based on the results achieved in creating a climate that encourages the development of competition. The compatibility of legislation with the European Union standards and its practical application are the basic assumptions of the purposeful operating of institutions. The modest results of the competition policy in Serbia impose the need to increase institutional capacity, upgrade the regulation and its conceiving in a manner that will ensure the construction of an efficient market economy. In this sense, the paper analyzes the key elements of the institutional framework that determine the effectiveness of the competition policy. Special attention will be paid to the practical application of this framework, which will be illustrated by a critical review of the manner and method of decision-making by the Serbian Commission for the Protection of Competition in its procedures in monopolized markets.
\end{abstract}

Keywords: competition policy, institutions, monopoly, market, Serbia and West Balkan countries

JEL Classification: D02, D42, K21

\section{INTRODUCTION}

One of the main tasks of any country is to create a favorable environment for the expression of individual preferences of the population and economic entities, and their alignment with collective preferences. In the economic area, it means creating conditions for achieving enterprises' and consumers' goals, which

\footnotetext{
* Correspondence to: B. Stojanovic, Faculty of Economics, University of Nis, Trg kralja Aleksandra Ujedinitelja 11, 18000 Nis, Serbia; e-mail: stojanovic@ni.ac.rs
}

leads to economic efficiency, both at the micro level and the level of the entire economy. According to that, an important task of the government is creating a necessary market infrastructure, i.e. market institutions. The market is not stochastic; it is an arranged set of supply and demand relationships. With adequate legal regulations, the government clearly determines the framework of economic entities' behavior and stability in expressing their interests and achieving goals. By clearly defining the rules of conduct and the scope for the economic activity, the state impacts the relationship between economic actors 
and the environment and also creates conditions for achieving the highest possible level of social welfare.

In economic theory, the potential effectiveness of economies is known to be based on competition. Proceeding from this, economic theory is directly or indirectly used for designing legislation in the competition area. In addition, it must indicate the mode of the application of positive legislation.

The first task is related to defining the standards which legislation must follow in deciding on a possible violation of competition conditions. These are the socalled conditions of effective competition. Competition could accomplish more functions. One of the most important is to protect market participants from the excessive market power of firms and abuses that can arise from it. In this way, the state takes over a general social task which basically boils down to the protection of individuals and firms. Another important goal is to improve the ability of companies and their technical progress. These targets lead to raising the standard of living and overall social progress.

The mission of the competition policy is to harmonize competition conditions in all parts of the market for all market participants. The openness of particular markets is a prerequisite for encouraging companies to be cost-effective, innovative and inventive. Increasing prosperity in companies increases the total welfare. Unbridled competition, which involves the free movement of goods, services, capital and people, opens the door to a synergetic effect of different factors. In doing so, the market should be free from the negative consequences of the government's influence, illegal actions and non-tariff barriers between countries. The task of economics is to define the relevant market and identify the abuse of the dominant position. Additionally, it is important that an analysis of apotential distortion of competition, created by merging companies on the relevant market, should be carried out. The Law on Competition regulates and often intervenes in cases of the violation of legal norms in this area. In fact, it seems ironic that control and intervention should promote free competition. The second paradox concerns the democratic principle of the freedom of individuals which opposes the freedom of the redefinition of their relationship (Jones \& Sufrin, 2001, 6).
The competition policy involves a very complex process that, in some segments, may evenbe controversial. The fact is that monopolies are desirable in certain industries and atcertain moments. To add, the determination of the relevant market involves a high degree of arbitrariness and subjectivity, the control of concentrations is based on assumed (future) effects on the competition intensity and economic efficiency. Because of that, the process of defining specific goals of the competition is impossible to standardize precisely, and the competition policy is under constant pressure of a shallow and superficial analysis as well as intentions of business and political circles to present market conditions in accordance with their own interest positions (Stojanović \& Radivojević, 2010, 337).

However, this area is characterized by frequent differences inscientific experts'opinions, and even those expressed by members of the state body for the protection of competition. When these differences in opinions become particularly large, there is a doubt about the authenticity of research results, and even the legal merits of a particular procedure. Nocompetition system is exempt from these differences; however,they seem to be more common in countries applying them for a short period of time, such as almost all transitional economies. Typically, in such countries, their regulations and practical activity in this area arenot sufficiently defined and reliable. The main reason for this is a lack of an institutional framework and an inadequate implementation of the law.

In developed countries, competitive institutions have gradually evolved over hundreds of years into effective ones due to the present form. Serbia has beentrying to make up for the part ofthat historic delay since 2005, and, by using good economic concepts and accumulated experience, to carry out quick reforms and build new and efficient institutions in this field.

One of the most powerful incentives for (economic) reforms in Serbia is itsmembership with theEuropean Union (EU). The integration process involves building an institutional infrastructure compatible with modern institutions of developed market economies. In the field of the competition policy, it comprisesthe adoption of laws, the establishment of regulatory bodies and the practical activity aligned with the competition policy in the EU. However, the formal harmonization of the 
regulatory framework with legal regulations in the $\mathrm{EU}$, with the lack of its practical application, only temporarily satisfies the standards of the Stabilization and Association Agreement and does not lead to the establishment of effective competition in the market. Disposing of substantial reforms carries on the risk that the accumulated problems will significantly limit economic efficiency and economic growth in the future, thus makingthe process of satisfying other (future) requirements for the EU accession more difficult.

Using the method of scientific observation and testing, and the method of a comparative analysis, the paper tests the hypothesis of an underdeveloped institutional framework for the effective implementation of the competition policy in Serbia. The aim of the paper is to point out the advantages and disadvantages of the competition policy institutional framework in Serbia and accordingly formulate valid recommendations for the policy implementation in the future through a critical consideration of all its aspects.

\section{COMPETITION AND ECONOMIC EFFICIENCY}

The competition policy is an important part of the economic policy determining general conditions for economic entities' behavior in the market. It involves defining the goals, instruments and holders of the measure implementation (policy-makers). The market functionality is realized by providing conditions for anefficient and open market economy through preventing or removing market restrictions. The competition policy includes the following activities: analyzingthe market relationships, diagnosingthe competition limits, taking measures to stimulate competition and identifying and implementing measures for the protection of competition. The main objective of these activities is to provide and maintain competition conditions through: 1) eliminating artificial and voluntary activities of the companies or countries having a weakening influence on the competition and 2) improving competition conditions with respect to natural limitations (Stojanović, 2003, 27). In an effort to achieve the goals of the competition policy, the regulatory role of the responsible state and/or independent institutions is essential. Due to aninherent tendency to restrict the competition, the authorities have an obligation to take measures against the holders of the alleged actions. The measures of the protection of competition are directed towards companies, on the one hand, and thestate or quasigovernmental funds, on the other.

At the EU level, which puts a positive landmark in the process of establishing the national systems and creating a national competition policy, the competition policy seeks to ensure a delicate balance of various objectives. All goals should promote effective competition by ensuring anefficient allocation of resources. Thus,the given task suggests an answer to the question what the subject of the competition policy is. It is the economic efficiency achieved by the competition in the market which provides the optimal allocation of limited resources. One of the primary intentions is the forming of competitive market structures. Proceeding from this, competition is a tool allowing the stability and total effective utilization of a business potential. The economic interests of the two basic types of economic (market) actors - enterprises and households - have an important place in the competition policy. Increasing competitive capacity and economic efficiency is related to another goal - to increasing consumer welfare. Therefore, competition is understood as a process of constant change in which the profit and usefulness are motives for an economic activity. In achieving the maximum profit, as a target function of firms, or the maximum utility as a target function of the consumer, transactions are conducted with agoal to achieve the economic optimum. In anopen-market economy, an increase in social welfare, with a discrete and selective control and authority over the behavior of economic agents, is achieved. This view of competition involves a dynamic process of building new institutions or upgrading the existing onesthat would contribute to achieving economic growth and development, thus improving the economic performance of the economy.

Pertaining to Serbia's commitment to the European integration processes, a competition policy compliant with the European standards should be designed.

An effective competition policy, able to provide quality competition and new players'smooth entry into the domestic market, has a positive impact 
on the competitiveness of the country, attracting foreign and domestic investments and influencing domestic companies' competences in their inclusion in competitive markets.

The Law on Competition is an important tool available to countries in the process of constituting an effective competition policy. In this sense, and as a necessary condition for thefunctioning market economy and progress of Serbia towards European integrations in recent years, it has beennoted that the adoption of the following two laws iscrucial: the Law on the Protection of Competition (LPC) and the Law on the State Aid Control (LSAC), which will reflect the basic rules of the EU in this area. It was necessary to legally round up anextremely important area, with significant implications forthe internal development and international position of the country.

\section{THE RESULTS OF THE COMPETITION POLICY IN SERBIA IN COMPARISON WITH NEIGHBOR COUNTRIES}

The achieved results of the competition policy implementation in Serbia as well as institutions' efficiency and the legal framework can be traced by analyzing globally-accepted indicators. The European Bank for Reconstruction and Development (EBRD) evaluates the progress of transition countries in the field of the competition policy by indicators ranging from 1 to 4.33. Indicator 1 means the absence of legislation and institutions for the protection of competition, while indicator 4.33 is given to the countries which achieve the standards and performance typical ofdeveloped countries (EBRD, 2011, 174). Serbia was evaluated with indicator 1 until 2006, when it scored 1.67for the first time. The merit for this can be attributed to the adoption of the initial Law on the Protection of Competition in 2005. Unlike Serbia, some neighbor countries had already recorded the first positive assessments at a much earlier date. Thus, Croatia was positively evaluated with indicator 2 forthe first time in 1996 (inthe same year, Albania scored 1.67), Macedonia in the year 2000, while Bosnia and Herzegovina (B $\& \mathrm{H})$ and Montenegro wereevaluated with 1.67 in 2006 and 2007, respectively. Table 1 shows the results of the competition policy implementation and the corresponding scores for Serbia and surrounding countries in the time period from 2001 to 2010.

According to the EBRD, Croatia - with a score of 3, which involves taking significant actions in the field of the competition policy and preventing the abuse of the dominant position - is the top ranked country in the region. Serbia, after the initial positive assessment of 1.67 in 2006, wasmakingprogress in the next year. After that, Serbia stagnated and the first positive step and its shiftingtoindicator 2.33 occurred in 2010. The nature of the EBRD indicators induces the fact that they are directly dependent on and conditioned by the development of institutions and legislation in the competition policy area.

Experience shows, and the current practice in Serbia fully confirms, that the most difficulties in transitional countries relate to forming a modern market structure

Table 1 The evaluation of the competition policy implementation in transitional countries

\begin{tabular}{lllllllllll}
\hline \multirow{2}{*}{ Country } & \multicolumn{10}{c}{ Year } \\
\cline { 2 - 11 } & 2001 & 2002 & 2003 & 2004 & 2005 & 2006 & 2007 & 2008 & 2009 & 2010 \\
\hline B \& H & 1 & 1 & 1 & 1 & 1 & 1.67 & 2 & 2 & 2 & 2 \\
Croatia & 2.33 & 2.33 & 2.33 & 2.33 & 2.33 & 2.33 & 2.67 & 2.67 & 3 & 3 \\
Macedonia & 2 & 2 & 2 & 2 & 2 & 2 & 2.33 & 2.33 & 2.33 & 2.33 \\
Montenegro & 1 & 1 & 1 & 1 & 1 & 1 & 1.67 & 1.67 & 2 & 2 \\
Serbia & 1 & 1 & 1 & 1 & 1 & 1.67 & 2 & 2 & 2 & 2.33 \\
\hline
\end{tabular}

Source: European Bank for Reconstruction and Development 2011 
that would be in function of providing intensive and effective competition between businesses entities. Accordingly, the competition policy implementation in Serbia is a very sensitive issue requiringa big loadhard work.

The extent to which Serbia is being faced with problems in the competition policy implementationand the manner in which it reflects its international competitiveness is clearly accounted forin the World Economic Forum study for the year 2011. According to this study, out of 142 monitored countries, Serbia is ranked at the 95th place, with a score of 3.88 (World Economic Forum, 2011, 314). Analyzing the reasons that led to a relatively low index of Serbia's international competitiveness, it is evident that a particular weakness lies in the low ranking of some "pillars of international competitiveness". Namely, out of twelve "pillars of competitiveness", Serbia has the worst ranking in terms of goods market efficiency (132nd place). However, it is necessary to identify the weakest "sub-pillars of international competitiveness" to complete the analysis of Serbia's low global competitiveness, namely: the effectiveness ofthe anti-monopoly policy (rank 137) and the extent of the market dominance (rank 139).

Table 2 The intensity of competition and the effectiveness of the anti-monopoly policy, 2011

\begin{tabular}{lcccc}
\hline \multirow{2}{*}{ Country } & \multicolumn{2}{c}{$\begin{array}{c}\text { Effectiveness of anti- } \\
\text { monopoly policy }\end{array}$} & \multicolumn{2}{c}{$\begin{array}{c}\text { Extent of market } \\
\text { dominance }\end{array}$} \\
\cline { 2 - 5 } & $\begin{array}{c}\text { Value } \\
(1-7)\end{array}$ & Rank/142 & $\begin{array}{c}\text { Value } \\
(1-7)\end{array}$ & Rank/142 \\
\hline B \& H & 3.4 & 110 & 2.8 & 131 \\
Croatia & 3.7 & 94 & 3.1 & 119 \\
Montenegro & 3.9 & 79 & 4.0 & 46 \\
Macedonia & 3.6 & 96 & 3.4 & 92 \\
Serbia & 2.8 & 137 & 2.5 & 139 \\
\hline
\end{tabular}

Source: World Economic Forum, 2011

It is clear that such a low international competitiveness of Serbia imposes aneed to increase the institutional capacity and upgrade the regulation and design of the competition policy in a manner that will ensure the establishing of an efficient market economy.
THE INSTITUTIONAL AND ADMINISTRATIVE CAPACITY FOR THE IMPLEMENTATION OF THE COMPETITION POLICY IN SERBIA

\section{The protection of competition in the context of the Law from 2005}

The Law on Competition was adopted in Serbia in 2005, by which the Antimonopoly Law, having been in force between 1996 and 2005, and having not generated meaningful results, was abolished. Despite the fact that the law represented a step forward in the field of the legal regulation of competition, it is evident now that ithad its shortcomings. The criticism and negative consequences of inadequate solutions in the law exceeded the benefits of its application. The subject matter of the law was being criticized. Article 1,defining the subject matterand purpose of the Law, cited that "the protection of competition in the market has been regulated, in order to ensure the equality of the market participants and encourage the economic efficiency and the achievement of theeconomic wellbeing of society as a whole, particularly consumers" (Law on the Protection of Competition, 2005). According to critics, there are several inaccuracies,even contradictions, in this respect. The objective of the law should be the protection of competition as a process whose unfolding brought numerousbenefits to society, and did not protect existing competitors (the equality of participants). Furthermore, the most criticized drawbacks of the Law from 2005 were tied to: a) penalties preventing or, at least, significantly impedingan effective action against those who violatethe Law, since the Commissionfor the Protection of Competition (Commission) had very limited powers to impose penalties and, practically, could only bring misdemeanor charges, b) an irrationally low threshold of the annual income giving rise to the obligation of thenotification of concentration, c) the position of the Commission and (to) guaranteeing its independence; d) exemptions from theapplying of the Law to persons engaged in the activities of a common interest (Skopljak, 2007, 66).

The approving of the market concentration is a function which was completely left to the Commission. However, the extremely low threshold for the 
notification of the concentration (the annual income of all parties in the concentration more than 10 million euros) led to a series of problems. Given the easy feasibility of the mentioned income level, this legal definition of the threshold resulted in overloadingthe Commission throughrequests for the approval of the concentration. In this manner, the Commission had little time for focusing on more important cases of the distortion of free competition, the abuse of the dominant position and restrictive agreements. In addition, , the doublemeaning and a lack of precision in defining the dominant position of the relevant market and the relevant geographic marketwere pointed out as the shortcomings of the Law. Finally, the Law gave the government a hugediscretion in prescribing the conditions, criteria and regulations toregulateeach relevant area of the competition policy. As a result of the above mentioned, after a relatively short period of time, a need for making changes in the legislation emerged, as well as did knowledge that such a change is not sufficientby itself. In addition to the modifications of the law, it was equally important to work on the adoption of an appropriate methodology for making decisions on the protection of competition, in accordance with the practices of leading European Commissions (Labus, 2008, 18).

After the Law from 2005, the Stabilization and Association Agreement (SAA) was signed in the year 2008, which featured the protection of competition as one of Serbia'smost important obligations in the EU integration process (The Stabilization and Association Agreement, 2008). Depending on theway competition is distorted in the Single European Market, the Community Competition Law includes several parts: restrictive practices and cartels, the abuse of the dominant market position and control of integration, the state aid and state monopolies (Spasić, 2007, 62). The SAA contains provisions closely aligned with much of the legislation and the intentions of the EU in the field of competition. By signing the Agreement, Serbia has accepted the obligation of building institutions and adopting a legal framework that will encompass all these areas of the Community Competition Law. In this way, the question of competition in Serbia has gained its international dimension, due to the fact that the domestic economy, because of itssize and geographic positioning, cannot be excluded from global flows. Any restrictive agreement and any abuse of the dominant position may have cross-border effects, the fight against anticompetitive behavior in Serbia is no longera mereobligation of the state towards its citizens, but also its international obligations towards the EU (Graić-Stepanović, 2007, 5). All requirements arising fromthe SAA in terms of competition, except for the area of the state aid, were covered by the Law on the Protection of Competition and did not constitute a novelty. The only novelty was the international control and supervision of the implementation of the defined rules.

\section{The protection of competition in the context of the Law from 2009}

As a result of the inefficiency and lack of results of the old law from 2005, the new Law on the Protection of Competition wasadopted in Serbia in 2009. The aim was to remove the criticized shortcomings of the old law in order to finallycreate conditions for fair competition, which wouldcontribute to the realization of the internal priorities of the country and meet its international obligations. Since the new law is compatible with the prevailing rules of the EU in the field of the competition policy, its use is expected to ensure an improved quality of the supply of goods and services to citizens at a lower cost and tocontribute to Serbia'sintegration process. The emphasis is on the efficient sanctioning of the distortion of competition, providing more efficient ways to prevent the abuse of the dominant market position and the control of the creation of market integration. The law gives more powers to the Commission, which will be more effective in proving the existence of abuses and will punish the perpetrators. The increased threshold for the obligatory notification of the concentration at 20 million euros and, in that sense, the relieved capacity of the Commission will be putin the service of preventing more serious cases of the distortion of competition.

The specific objectives of the concept of the new law can be systematized as follows: a) the specifying and adequate transposition of the material competition rules applicable in the EU, b) the reduction of the burden of administrative procedures for business entities in 
the sense of obligations of notification, by raising the control threshold, c) creating legal and organizational conditions for capacity building and the expansion of procedural powers of the Commission; d) authorizing the Commission to implement effective and applicable measures in the cases of the distortion of competition; e) the improvement of the procedural and legal regimes (Graić-Stepanović, 2007, 6). The law provides a systematic and meaningful way of determining the basic legal institutions and terms in the field of competition. The procedure determiningapotential distortion of competition has been rutting in front of the Commission ina comprehensive manner, with apossibility of the participation and cooperation of all stakeholders.

\section{Authorizations of the Commission for the Protection of Competition}

The Commission for the Protection of Competition was formed in 2005. However, the fundamentalproblems of the protection of competition in Serbia after 2005 have beenrelated to the inefficient workof the Commission. The lack of operational and financial independence has beencriticized, since the Commission was financed from the state budget. In addition to this, its competencies defined by the Law from 2005 havenot been clear enough and have giventhe government a broad discretion in this area. The limited capacity of the Commission and its overload due torequests for the approving of the concentration have beenpointed out as problems, which, again, is a consequence of an inadequate legal regulation of the matter. The new Law from 2009 made several important alterationsin the domain of the Commission's actions. Speaking about the prosecution of investigation, the old LPC predicted an agreement (an order) by the state authorities for the examination of the official and other premises of the party. The new LPC does not provide anapproval of the competent state authorities and does give very broad authorizations in the performance of inspections. The new LPC also allowsan unannounced investigation, if there are grounds to believe that there is a danger of removing or altering evidence of a party or a third person (Article 52). The old LPC envisaged proposals for provisional measures by the parties, by which the Commission has brought a decision on the termination of the distortion of competition and taking actions toeliminate their harmful consequences. The new LPC does not provide the submission of proposals for provisional measures. Under the old LPC, the Commission for the Protection of Competition did not specify administrative measures. However, the new LPC provides the Commission with this jurisdiction in Article 57: "If the Commission finds a distortion of competition or another distortion of this Law, the Commission will determine a measure for the protection of competition, a measure eliminating the distortion of competition, or another administrative measure prescribed by this law" (Law on the Protection of Competition, 2009, 18).

In the new LPC, two types of measures to remove a distortion of competition are defined: behavioral measures and structural measures. The Commission may determine measures aimed at eliminatingadistortion of competition and at preventingapossibility of the same or similar distortions in a decision by which a distortion of competition is established, by giving orders to behave in a particular way or prohibit certain behavior (a behavioral measure). However, if a significant risk of repeating the same or similar distortion is determined as a direct result of the structure of market participants, the Commission may determine ameasure that would be aimedatchanging this structure in order to eliminate such adventures, and at establishingthestructure that existed before the violation (structural measures). The new LPC provides themeasure of a procedural penaltyin article 70 , according to which it is determined that a market participant should pay penalties in the amount of 500 euros to 5.000 euros for each day of conduct contrary to the Commission's order given in the proceedings.

\section{The administrative capacity of the Commission for the Protection of Competition}

Notwithstanding the undeniable progress in the legal regulation of the activities carried out by the Commission, it is still necessary that its institutional and administrative capacity should be promoted and its personnel be continuously educated and trained for taking an effective action. It is needed that an emphasis should be put on building an institutional capacity 
and providing professional staff for the purpose of an economic analysis, in order to timely detect a distortion of competition in the market. Furthermore, it is necessary the work of similar bodies in other countries should be monitored in order to learn on the experiences of countries with a good antitrust practice. According to a report from the year 2010, the national Commission employs a total of 29 people. Seventeen employees are entrusted with tasks which are the scope of the Commission (work on subjects), two persons are employed in the Domestic and International Cooperation Sector, while 10 employeesdeal with joint operations for the sectors directly concerned with the protection of competition. Comparing the number of employees in the national Commission and the number of employees in the bodies of the Competition in EU member states, ageneral conclusion can be reachedthat Serbia has fewer employees. However, this comparison should be viewed as provisional, some national bodies for the protection of competition exercise consumer protection, state aid and public procurement control (Commission for the Protection of Competition, 2011a, p. 8). Graph 1 shows the comparative view of the number of employees in the bodies of the Competition in Serbia and countries in the region in the year 2010, in total and on the work scope of the Commission (work on subjects).

Compared with neighbor countries, Serbia has a greater number of employees, in total and on the subjects, than most countries. Thenumber of employees is higher only in the Croatian body for the protection of Competition, but it is a country in the region with the best antitrust practice.

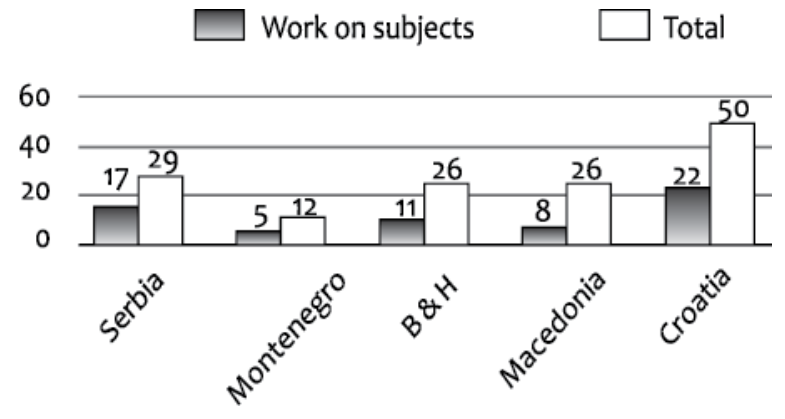

Graph 1 The number of employees in the bodies for the protection of competition (2010)

Source: Ganon \& Petaković, 2011, 94

The predominant activity of the national Commission from its constitution in the year 2005 was the one of approving theconcentration. Significant forms of the distortion of competition in the market, the abuse of the dominant position and restrictive agreements, were far less common in the practice of the Commission. Table 3 accounts foran overview of the subjects of the national Commission for the Protection of Competition in the time period from 2006 to 2010.

Only in 2010 was there a reduction in the number of requests for approving the concentration. This is the result of passing a new law that increased the threshold of the total annual revenue requirement for a mandatory notification of concentration (in the previous law, it had beenset at an unrealistically low level). However, there was an increase in the number of cases considering the abuse of the dominant position and

Table 3 Case review of the Commission for the Protection of Competitionin Serbia (2006 - 2010)

\begin{tabular}{lccccc}
\hline & 2006 & 2007 & 2008 & 2009 & 2010 \\
\cline { 2 - 6 } Restrictive agreements & 1 & 4 & 20 & 16 & 9 \\
Exemption from restrictive agreements & 1 & 4 & 8 & 7 & 5 \\
Abuse of dominant position & 10 & 13 & 2 & 19 & 6 \\
Concentrations of market participants & 47 & 125 & 137 & 116 & 75 \\
Total & 58 & 146 & 167 & 158 & 95 \\
\hline
\end{tabular}

Source: Annual Reports of the Commission for the Protection of Competition, 2006 - 2010 
restrictive agreements between market participants. Graph 2 demonstrates a comparative overview of the number of notifications of concentrations in Serbia and countries in the region.

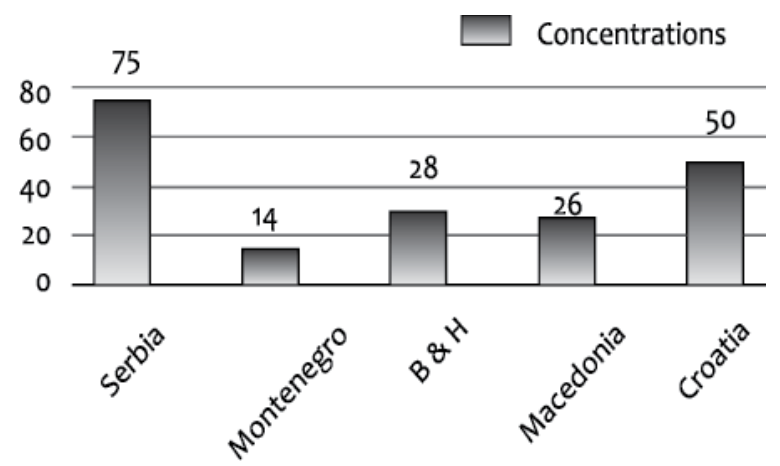

Graph 2 The number of notifications of concentration in Serbia and countries in the region (2010)

Source: Ganon \& Petaković, 2011, 96

Notwithstanding the fact that the number of applications of concentrations to the Commission was undoubtedly reduced in 2010, Serbia still has the highest number of applications in comparison with the countries in the region. The intention of the new law that the capacity of the Commission should serve the purpose of the control and sanctioning of serious disturbances in the market hasnot ledto major positive changes.

\section{The consequences of an inadequate institutional capacity}

On the basis of the previous analysis of the regulatory framework, the institutional and administrative capacities of the Commission, it is clear that it is not given due weight to the protection of competition in Serbia. Therefore, the Serbian economic system isnot amarket system in anordinary sense. Laws are (were) usually poor and often not referred to, and the state and politics informally assumed the role of an omnipotent arbiter which predominantly affects all economic flows.
Political interference in this area has generated frequent differences inexpert and impartial circles' opinions and analyses, and eventhe opinions and analyses made and conducted, respectively, by the representative body for the protection of competition. When these differences in attitudes seem as particularly large, a doubt in the obtained researches and even in the legal basis of a particular procedure grows. The procedure that the Commission implemented against the company Danube Foods Group (Commission for the Protection of Competition, 2008, Commission for the Protection of Competition, 2011b) or the attempts to prohibit the acquisition of Hellenic Sugar by the company Sunoko are among them (Stojanović \& Radivojević, 2011, 480484; Commission for the Protection of Competition, 2012).

One illustration of the condition of competition in the Serbian markets is the recently-adopted Regulation on the Limitation of Margins on Basic Foodstuffs (Regulation on Special Conditions of Certain Goods Traffic, 2011). If a higher level of competition existed inthis market, the margin would be within a normal framework, and it would not be necessary for the Regulation to be adopted. Thus, the state indirectly affected the retailpricing with its interventionist measures, which suggests that the state is not (was not) able to establish effective competition in this market by means of the instruments of the competition policy. Also, the mentioned Regulation has had a negative impact on small retailers (the so-called shops in the neighborhood), whose business largely depends on the margins on basic foodstuffs. A large number of such shops were forced to suspend their business or operate at aconsiderable loss by restricting the margins on these products. According to the Serbian Employers Union, 875 small shops were closed and 3,430 people lost their jobs in the time period from 1 January (when the Regulation entered into force) to 15 February 2012.

It is quite legitimate to ask what the situation is like whenmargins on products not classified as basic foods are concerned. Since such products are not used to meet the basic needs, they can be divided into groups of more or less luxury goods, and it is quite reasonable to have a doubt that margins on some of these products do exceed $50 \%$. 


\section{CONCLUSION}

Whether because of the inadequate legislation, a lack of an institutional capacity, incompetence, political pressure or something else, it seems that the competition policy in Serbia is de facto a policy of protecting monopolies from competitors. In the absence of a comprehensive and coherent, harmonized and long-term strategy of institutional reforms, it can result in theoverlapping of and even conflicting withsome institutional interventions, the waste of professional resources, time and money, and an increase inother dysfunctional costs.

This is not pleading for a rigid and centralized reforming option; however, it is pleading for planned and coordinated reform interventions that will raise institutionalization processes tothe level of the standards established by developed countries, with anaim to reduce the existing institutional deficit.

The created transitional recession occurred as a result of economic restructuring and adjusting to new business conditions without a synchronized change of institutions.In addition, it seems that a political consensus on the necessity of a radical intervention in the competition policy areawas not reached. Considering the delay in creating a legal basis and appropriate institutions, it is necessary that the regulation of this important area in transitional economies should continuously be improving. This is one of the preconditions for thefundamental reconstruction of the economy and society. Without leaving the strategic orientation, the creators of transition processes in Serbia need to makecorrections in designing and implementing economic and systemic solutions, eliminate the discrepancy between the norms and the currentsituation, and thus prevent the already achieved results from being compromised. Starting from the poor performance of the economy and the inefficiency of institutions, a clear criticism was madeofthe previous engineering of transition in the field of the competition policy in paper. Thus, a basis for further research and the identification of the causes was created, describing the characteristics and establishment of a tendency in the development of this important area of the economic policy.

\section{REFERENCES}

European Bank for Reconstruction and Development (EBRD) (2011). Transition Report 2011 - Crisis and Transition: The People's Perspective, http://www.ebrd.com/

Ganon, P., \& Petaković, R. (2011). U fokusu: Konkurencija. Beograd, Srbija: AOD Karanović i Nikolić.

Graić-Stepanović, S. (2009). Efekti pristupanja Srbije Evropskoj uniji - politika konkurencije. Konkurencija. Beograd, Srbija: Fakultet za ekonomiju, finansije i administraciju.

Jones, A., \& Sufrin, B. (2001). EC Competition Law. Oxford, UK: Oxford University Press.

Комисија за заштиту конкуренције Републике Србије. (2008). Pemerbe od 25. jaнyара 2008.

Комисија за заштиту конкуренције Републике Србије. (2011а). Годиштьи извештај о раду Комисије за заштиту конкуренције за 2010.

Комисија за заштиту конкуренције Републике Србије. (2011b). Решенье бр. 5/0-02-43/2011. од 24. јануара 2011.

Комисија за заштиту конкуренције Републике Србије. (2012). Решенье бр. 6/0-02-18/2012-3. од 19. јануара 2012.

Labus, M. (2008). Analiza tržišne koncentracije: Primer C / C market. Beograd, Srbija: Belox Advisory Services.

Ristić, B. (2010). Sprovođenje antimonopolske politike u Srbiji: dosadašnja iskustva i preporuke. Kvartalni monitor, 19, 6880 .

Skopljak, Z. (2007). Godinu dana rada Komisije za zaštitu konkurencije. Kvartalni monitor, 8.

Spasić, I. (2007). Komunitarno pravo konkurencije. Strani pravni život, (1-2)

Споразум о стабилизацији и придруживаюу. (2008). Службени гласник Републике Србије, 83.

Stojanović, B. (2003). Tržište Evropske unije - konkurencija $i$ trgovinska politika. Niš, Srbija: Ekonomski fakultet Univerziteta u Nišu.

Stojanović, B., \& Radivojević, V. (2010). Koncentracija ponude kao izraz nesavršenosti tržišta: Primer nespecijalizovane trgovine na malo na tržištu grada Niša. Ekonomika preduzeća, 58(7), 327-338.

Stojanović, B., \& Radivojević, V. (2011). Economic Glance at Antitrust Legislation in Serbia and Others Western Balkan 
Countries: Case Study - Dairy Products Market. Journal for Bussines and Economics, 2(6), 472-487.

Влада Републике Србије (2011). Уредба о посебним условима промета одређене робе. Службени гласник Републике Србије, 102.
World Economic Forum. (2011). Global Competitiveness Report 2011-2012. http://www.weforum.org/

Закон о заштити конкуренције. (2005). Службени гласник Републике Србије, 79.

Закон о заштити конкуренције. (2009). Службени гласник Републике Србије, 51.

Boban Stojanovic is a Professor at the Faculty of Economics, University of Nis, Serbia. Doctorate degree earned at the Faculty of Economics, University of Belgrade. His areas of scientific researche are monopolies, competition policy, EU market. He is a member of editorial boards - Journal of business and economics, Panoeconomicus.

Vladimir Radivojevic is a Ph.D. student at the Faculty of Economics, University of Nis, Serbia. Fields of his interest are market analysis, imperfect market structures, competition policy.

Tanja Stanisic is a Ph.D. student at the Faculty of Economics, University of Nis, Serbia. She is a researcher at the Project No. 179066, founded by the Ministry of Science of the Republic of Serbia. 


\title{
INSTITUCIONALNE PRETPOSTAVKE EFIKASNOSTI POLITIKE ZAŠTITE KONKURENCIJE
}

\author{
Boban Stojanović,* Vladimir Radivojević, Tanja Stanišić \\ Ekonomski fakultet Univerziteta u Nišu
}

\begin{abstract}
Preduslov za uspešno sprovođenje politike zaštite konkurencije kao temelja tržišne ekonomije je adekvatno normativno regulisanje. Sa aktuelnim zakonskim rešenjima u oblasti zaštite konkurencije, Srbija je obezbedila neophodan institucionalni okvir za efikasno funkcionisanje tržišta i uspostavljanje delotvorne konkurencije na njemu. Efikasnost tog okvira neophodno je ocenjivati analizom tržišta, a na osnovu rezultata postignutih u kreiranju ambijenta koji podstiče razvoj konkurencije. Kompatibilnost pravne regulative sa standardima Evropske unije i njena dosledna praktična primena predstavljaju osnovne pretpostavke svrsishodnog funkcionisanja institucija. Skromni rezultati politike zaštite konkurencije u Srbiji nameću potrebu za povećanjem institucionalnog kapaciteta, dogradnjom regulative i njenim koncipiranjem na način koji će obezbediti izgradnju efikasne tržišne privrede. U tom smislu, u radu se istražuju ključni elementi institucionalnog okvira koji opredeljuju efikasnost politike zaštite konkurencije. Posebna pažnja se posvećuje praktičnoj primeni ovog okvira, što je ilustrovano kritičkim osvrtom na način i metod odlučivanja Komisije za zaštitu konkurencije u vođenju postupaka na monopolizovanim tržištima.
\end{abstract}

Ključne reči: zaštita konkurencije, institucije, monopol, tržište, Srbija i zemlje u okruženju

JEL Classification: D02, D42, K21

\section{UVOD}

Jedan od osnovnih zadataka svake države je stvaranje što povoljnijeg ambijenta za ispoljavanje individualnih preferencija stanovništva i privrednih subjekata i njihovo usklađivanje sa kolektivnim preferencijama. Na ekonomskom planu to znači stvaranje preduslova za ostvarivanje ciljnih funkcija preduzeća i potrošača, što vodi efikasnosti privređivanja, kako na mikro nivou, tako i na nivou cele privrede. Stvaranje

\footnotetext{
* Korespondencija: B. Stojanović, Ekonomski fakultet Univerziteta u Nišu, Trg kralja Aleksandra Ujedinitelja 11, 18000 Niš; e-mail: stojanovic@ni.ac.rs
}

neophodne tržišne infrastrukture, odnosno, institucija tržišta pri tome predstavlja važan zadatak države. Tržište nije stohastično, već predstavlja uređeni skup odnosa ponude i tražnje. Uz to, adekvatnom pravnom regulativom država jasno određuje okvire ponašanja ekonomskih subjekata, stabilnost $\mathrm{u}$ ispoljavanju interesa i ostvarivanju ciljeva. Jasnim definisanjem pravila ponašanja i prostora za ekonomsku aktivnost država utiče na odnos ekonomskih aktera i okruženja stvarajući uslove za postizanje što većeg stepena društvenog blagostanja.

U ekonomskoj teoriji su poznate potencijalne efikasnosti privreda zasnovanih na konkurenciji. 
Polazeći od toga, ekonomska teorija direktno ili indirektno služi za osmišljavanje zakonske regulative $\mathrm{u}$ oblasti konkurencije. Ona uz to mora da ukaže na način primene pozitivnog zakonodavstva.

Prvi zadatak se svodi na definisanje normi od kojih mora da pođe pravna regulativa $u$ odlučivanju o eventualnom narušavanju uslova konkurencije. To su uslovi tzv. efektivne konkurencije. Konkurenicija bi trebalo da ostvari više funkcija. Jedna od najvažnijih je zaštita tržišnih aktera od prekomerne tržišne moći preduzeća i zloupotreba koje mogu iz toga da proisteknu. Na taj način se preuzima i opštedruštveni zadatak koji se u osnovi svodi na zaštitu pojedinaca i preduzeća. Drugi značajan cilj koji se ostvaruje zaštitom konkurencije je podizanje sposobnosti preduzeća i njihovog tehničkog napretka. Ovi ciljevi vode ka podizanju životnog standarda stanovništva i opštem društvenom napretku.

Misija politike zaštite konkurencije je ujednačavanje uslova konkurencije na svim delovima tržišta i za sve tržišne aktere. Pri tome je otvorenost pojedinačnih tržišta uslov za podsticanje preduzeća na ekonomičnost, inovativnost i inventivnost. Povećanjem blagostanja u preduzećima povećava se i ukupno blagostanje. Neometana konkurencija koja podrazumeva slobodno kretanje dobara, usluga, kapitala i ljudi otvara prostor za sinergijsko delovanje različitih faktora. Pri tome bi tržište trebalo biti oslobođeno negativnih posledica uticaja vlada, nezakonskih supsidija i netarifnih barijera između zemalja. Zadatak ekonomske nauke je definisanje relevantnih tržišta i identifikovanje zloupotrebe dominantnog položaja. Uz to, važna je i analiza potencijalnog narušavanja konkurencije nastalog spajanjem preduzeća sa relevantnog tržišta. Pravo konkurencije reguliše, a često i interveniše $u$ slučajevima povreda pravnih normi u ovoj oblasti. Deluje ironično da se kontrolom i intervencijom treba promovisati slobodna konkurencija. Drugi paradoks se tiče demokratskog načela slobode pojedinaca koji se suprotstavljaju slobodi uređenja njihovih odnosa (Jones \& Sufrin, 2001, 6).

Politika zaštite konkurencije podrazumeva veoma složen proces koji u određenim segmentima može biti čak i kontroverzan. Činjenica je da su monopoli $\mathrm{u}$ određenim sektorima privrede $\mathrm{i} u$ određenom trenutku poželjni. Uz to, postupak određivanja relevantnog tržišta podrazumeva visok stepen arbitrarnosti i subjektivnosti, a kontrola koncentracija se vrši na osnovu pretpostavljenih (budućih) efekata po intenzitet konkurencije i ekonomsku efikasnost. Zato je proces definisanja određenih ciljeva zaštite konkurencije nemoguće precizno standardizovati, a politika zaštite konkurencije je pod stalnim pritiskom površnih i instruisanih analiza, kao i namera određenih poslovnih i političkih krugova da stanje na tržištu predstave $\mathrm{u}$ skladu sa sopstvenom interesnom pozicijom (Stojanović \& Radivojević, 2010, 337).

Ovu oblast, međutim, karakterišu i česta razmimoilaženja u stavovima naučne i stručne javnosti, pa čak i predstavnika tela za zaštitu konkurencije. Kad se te razlike u stavovima pokažu kao posebno velike, narasta sumnja u dobijene istraživačke nalaze, pa čak i u zakonsku zasnovanost određenog postupka. Nijedan sistem zaštite konkurencije nije oslobođen ovih razlika, ali se čini da su one učestalije u zemljama sa nedovoljnim iskustvom u njegovoj primeni. Po pravilu, u takvim zemljama regulativa i praktična aktivnost u ovoj oblasti nije dovoljno i pouzdano definisana. Osnovni razlog za to je nedovoljno izgradjen institucionalni okvir.

U razvijenim zemljama institucije zaštite konkurencije su postepeno evoluirale, da bi dospele do današnjih efikasnih oblika. Srbija zvanično od 2005. godine pokušava da nadoknadi makar deo tog istorijskog zakašnjenja i, koristeći dobre ekonomske koncepte i nagomilana iskustva, brzo izvede reforme i izgradi nove i efikasne institucije u ovoj oblasti.

Jedan od najsnažnijih podsticaja (ekonomskim) reformama $u$ Srbiji jeste učlanjenje $u$ EU. Proces pridruživanja podrazumeva izgradnju institucionalne infrastrukture kompatibilne sa modernim institucijama razvijenih tržišnih privreda. U oblasti zaštite konkurencije $u$ Srbiji to znači usvajanje zakona, formiranje regulatornih tela i praktičnu aktivnost usklađenu sa intencijama politike zaštite konkurencije u EU. Međutim, formalna harmonizacija regulatornog okvira sa zakonskim rešenjima u EU, uz izostanak njegove dosledne primene, samo prividno i privremeno zadovoljava standarde Sporazuma o stabilizaciji i pridruživanju i sama po sebi ne dovodi do uspostavljanja delotvorne konkurencije na tržištu. Odlaganje suštinskih reformi nosi rizik da nagomilani 
problemi bitno ograniče ekonomsku efikasnost i privredni rast $u$ narednom periodu, a time i otežaju zadovoljavanje drugih (budućih) uslova za pristupanje EU.

U radu se metodama naučnog posmatranja i ispitivanja i metodom komparativne analize testira hipoteza o nedovoljno razvijenom institucionalnom okviru za efikasno sprovođenje politike zaštite konkurencije u Srbiji. Cilj je da se kroz kritičko sagledavanje svih aspekata institucionalnog okvira politike zaštite konkurencije u Srbiji ukaže na njegove prednosti i nedostatke i u skladu sa tim formulišu validne preporuke za vođenje ove politike $u$ narednom periodu.

\section{KONKURENCIJA I EKONOMSKA EFIKASNOST}

Politika zaštite konkurencije je važan deo ekonomske politike kojom se ekonomskim subjektima određuju okvirni uslovi za ponašanje na tržištu. Ona obuhvata definisanje ciljeva, sredstava i nosilaca sprovođenja mera (kreatora politike). Funkcionalnost tržišta se pri tome ostvaruje obezbeđivanjem uslova za efikasnu i otvorenu tržišnu privredu sprečavanjem ili odstranjivanjem tržišnih ograničavanja. U domenu politike zaštite konkurencije analiziraju se odnosi na tržištu, dijagnosticiraju ograničenja konkurencije, preduzimaju mere za stimulisanje konkurencije i utvrđuju i sprovode mere zaštite konkurencije. Osnovni cilj svih tih aktivnosti je obezbeđivanje i očuvanje uslova konkurencije kroz: 1) otklanjanje veštačke, svojevoljne aktivnosti preduzeća ili države koje utiču na slabljenje konkurencije i 2) poboljšanje uslova za konkurenciju uz uvažavanje prirodnih ograničenja (Stojanović, 2003, 27). U nastojanju da se ostvare ciljevi politike zaštite konkurencije neophodna je regulativna uloga nadležnih državnih i/ili nezavisnih institucija. Zbog imanentne težnje da se konkurencija ograniči, nadležni organi imaju obavezu preduzimanja mera protiv nosilaca inkriminisanih postupaka. Mere zaštite uslova konkurencije su usmerene, s jedne strane ka preduzećima, a, s druge strane, ka državnim ili paradržavnim fondovima.

Na nivou Evropske unije (EU), čija praksa predstavlja pozitivan reper u procesu uspostavljanja nacionalnih sistema i kreiranja nacionalnih politika zaštite konkurencije, politika konkurencije nastoji da obezbedi delikatan balans različitih ciljeva. Svi ciljevi bi trebalo da promovišu efektivnu konkurenciju tako što ce obezbediti efikasnu alokaciju resursa. Ovako postavljeni zadatak sugeriše odgovor na pitanje šta je predmet politike konkurencije. To je ekonomska efikasnost postignuta tako što bi konkurencija na tržištu obezbedila optimalnu alokaciju ograničenih resursa. Jedna od osnovnih intencija je zasnivanje konkurentnih tržišnih struktura. Polazeći od toga, konkurencija je instrument koji omogućava stabilnost i puno efektivno iskorišćenje potencijala privrednih subjekata. Ekonomski interesi dve osnovne vrste ekonomskih (tržišnih) aktera - preduzeća i domaćinstava - imaju značajno mesto u politici zaštite konkurencije. Povećanje konkurentnih sposobnosti i ekonomske efikasnosti povezano je sa drugim ciljem - povećanjem blagostanja potrošača. Konkurencija se zbog toga shvata kao proces stalnih promena u kojima su profit i korisnost motivi ekonomskih aktivnosti. $U$ ostvarivanju maksimuma profita kao ciljne funkcije preduzeća ili što veće korisnosti kao ciljne funkcije potrošača obavljaju se transakcije kojima se teži ekonomskom optimumu. U miljeu otvorene tržišne privrede ostvaruje se povećanje društvenog blagostanja, uz diskretnu i selektivnu kontrolu i ingerenciju nad ponašanjem ekonomskih subjekata. Ovakav pogled na konkurenciju podrazumeva dinamični proces izgradnje novih ili dogradnje postojećih institucija koje bi doprinele ostvarivanju ekonomskog rasta i razvoja, a time i poboljšanju ekonomskih performansi privrede.

Sa opredeljenjem za evropske integracione procese u Srbiji bi trebalo da se konstituiše politika zaštite konkurencije koja će biti usklađena sa evropskim standardima. Efikasna politika zaštite konkurencije, koja je u stanju da obezbedi kvalitetnu tržišnu utakmicu i neometani ulazak novih igrača na domaće tržište ima pozitivan uticaj na nivo konkurentnosti zemlje, privlačenju inostranih i domaćih investicija i kompetentnost domaćih preduzeća u uključivanju u konkurentsku utakmicu na razvijenim tržištima.

Pravo konkurencije je važno sredstvo koje stoji na raspolaganju državama $\mathrm{u}$ procesu konstituisanja efikasne politike zaštite konkurencije. U tom smislu, kao neophodan uslov za funkcionisanje tržišne 
ekonomije i napredak Srbije na putu ka evropskim integracijama u proteklim godinama bilo je istaknuto usvajanje dva zakona od suštinskog značaja, Zakona o zaštiti konkurencije (ZZK) i Zakona o državnoj pomoći, koji će odražavati osnovna pravila EU u ovom domenu. Bilo je potrebno pravno zaokružiti izuzetno važnu oblast, sa značajnim implikacijama i na unutrašnji razvoj i na međunarodnu poziciju zemlje.

\section{REZULTATI POLITIKE ZAŠTITE KONKURENCIJE U SRBIJI U POREĐENJU SA ZEMLJAMA U OKRUŽENJU}

Ostvareni rezultati Srbije u domenu politike zaštite konkurencije, kao i efikasnost institucija i utemeljenog pravnog okvira mogu se pratiti analizom globalno prihvaćenih indikatora. Evropska banka za obnovu i razvoj (EBRD) ocenama od 1 do 4,33 meri tranzicioni napredak zemalja u oblasti politike zaštite konkurencije. Ocena 1 podrazumeva nepostojanje zakonodavstva i institucija za zaštitu konkurencije, dok se ocena 4,33 dodeljuje zemljama koje su u domenu politike zaštite konkurencije postigle standarde i performanse tipične za razvijene industrijske zemlje (EBRD, 2011, 174). Srbija je ocenom 1 bila ocenjivana sve do 2006. godine, kada je po prvi put dobila ocenu 1,67. Zasluge za to se mogu pripisati usvojenom Zakonu o zaštiti konkurencije 2005. godine. Za razliku od Srbije, pojedine zemlje iz okruženja prve pozitivne ocene zabeležile su znatno ranije. Tako je Hrvatska prvi put pozitivno ocenjena i to ocenom 2 još 1996. godine (iste godine je i Albanija dobila ocenu 1,67). Postignuti rezultati u domenu politike zaštite konkurencije u Makedoniji se prvi put pozitivno ocenjuju 2000. godine ocenom 2, dok Bosna i Hercegovina (BiH) i Crna Gora dobijaju ocenu 1,67 u 2006, odnosno 2007. godini, respektivno. U Tabeli 1 prikazano je stanje $\mathrm{u}$ domenu politike zaštite konkurencije i pripadajuće ocene za Srbiju i zemlje u okruženju u periodu od 2001. do 2010. godine.

Prema indikatorima EBRD, najbolje rangirana zemlja u okruženju je Hrvatska sa ocenom 3, koja podrazumeva preduzimanje značajnih akcija $u$ oblasti zaštite konkurencije i sprečavanja zloupotrebe dominantnog položaja. Srbija je posle polazne pozitivne ocene od 1,67 u 2006. godini zabeležila napredak već naredne godine. Međutim, nakon toga dolazi do stagnacije i prvi pozitivan pomak i prelazak na ocenu 2,33 beleži tek u 2010. godini. Sama priroda indikatora EBRD indukuje njihovu direktnu zavisnost i uslovljenost razvijenošću institucija i zakonodavstva u domenu politike zaštite konkurencije.

Iskustva pokazuju, a aktuelna praksa $\mathrm{u}$ Srbiji to $\mathrm{u}$ potpunosti potvrđuje, da se u tranzicionim zemljama najveće teškoće odnose upravo na izgradnju moderne strukture tržišta koja bi bila u funkciji obezbeđivanja intenzivne i efektivne konkurencije između privrednih subjekata. U skladu sa time, primena politike zaštite konkurencije u Srbiji predstavlja veoma osetljivo pitanje koje zahteva mnogo strpljivog rada.

U kojoj meri se Srbija suočava sa problemima $\mathrm{u}$ sprovođenju politike zaštite konkurencije i kako se to odražava na njenu međunarodnu konkurentnost jasno govori studija Svetskog ekonomskog foruma za 2011.

Tabela 1 Ocene sprovođenja politike zaštite konkurencije u tranzicionim zemljama

\begin{tabular}{lllllllllll}
\hline \multirow{2}{*}{ Zemlja } & \multicolumn{10}{c}{ Godina } \\
\cline { 2 - 11 } & 2001 & 2002 & 2003 & 2004 & 2005 & 2006 & 2007 & 2008 & 2009 & 2010 \\
\hline BiH & 1 & 1 & 1 & 1 & 1 & 1.67 & 2 & 2 & 2 & 2 \\
Hrvatska & 2.33 & 2.33 & 2.33 & 2.33 & 2.33 & 2.33 & 2.67 & 2.67 & 3 & 3 \\
Makedonija & 2 & 2 & 2 & 2 & 2 & 2 & 2.33 & 2.33 & 2.33 & 2.33 \\
Crna Gora & 1 & 1 & 1 & 1 & 1 & 1 & 1.67 & 1.67 & 2 & 2 \\
Srbija & 1 & 1 & 1 & 1 & 1 & 1.67 & 2 & 2 & 2 & 2.33 \\
\hline
\end{tabular}

Izvor: European Bank for Reconstruction and Development, 2011 
godinu. Prema navedenoj studiji, od 142 posmatrane zemlje, Srbija zauzima 95. mesto sa ocenom 3.88 (World Economic Forum, 2011, 314). Analizirajući razloge koji su doveli do relativno niskog indeksa međunarodne konkurentnosti Srbije može se uočiti da posebna slabost leži u niskom rangu pojedinih "stubova međunarodne konkurentnosti". Naime, od ukupno dvanaest "stubova konkurentnosti", Srbija je najlošije rangirana u pogledu efikasnosti tržišta dobara (132. mesto). Međutim, radi kompletiranja analize niske konkurentnosti neophodno je identifikovati najslabije "podstubove međunarodne konkurentnosti", a to su: efikasnost antimonopolskog zakonodavstva (rang 137) i stepen dominacije na tržišstu (rang 139).

Tabela 2 Intenzitet konkurencije i efektivnost antimonopolske politike, 2011.

\begin{tabular}{lcccc}
\hline \multirow{2}{*}{ Zemlja } & \multicolumn{2}{c}{$\begin{array}{c}\text { Efektivnost antimo- } \\
\text { nopolske politike }\end{array}$} & \multicolumn{2}{c}{$\begin{array}{c}\text { Nivo tržišne } \\
\text { dominacije }\end{array}$} \\
\cline { 2 - 5 } & $\begin{array}{c}\text { Indeks } \\
(1-7)\end{array}$ & $\begin{array}{c}\text { Rang } \\
\text { (od 142) }\end{array}$ & $\begin{array}{c}\text { Indeks } \\
(1-7)\end{array}$ & $\begin{array}{c}\text { Rang } \\
\text { (od 142) }\end{array}$ \\
\hline BiH & 3.4 & 110 & 2.8 & 131 \\
Hrvatska & 3.7 & 94 & 3.1 & 119 \\
Crna Gora & 3.9 & 79 & 4.0 & 46 \\
Makedonija & 3.6 & 96 & 3.4 & 92 \\
Srbija & 2.8 & 137 & 2.5 & 139 \\
\hline
\end{tabular}

Izvor: World Economic Forum, 2011

Jasno je da ovako niska međunarodna konkurentnost Srbije nameće potrebu za povećanjem institucionalnog kapaciteta, dogradnjom regulative i koncipiranjem politike zaštite konkurencije na način koji će obezbediti izgradnju efikasne tržišne privrede.

\section{INSTITUCIONALNI I ADMINISTRATIVNI KAPACITET ZA SPROVOĐENJE POLITIKE ZAŠTITE KONKURENCIJE U SRBIJI}

\section{Zaštita konkurencije u kontekstu Zakona iz 2005.}

Zakon o zaštiti konkurencije u Srbiji usvojen je 2005. godine, čime je prestao da važi Antimonopolski zakon koji je bio na snazi od 1996. do 2005. godine i koji nije dao značajnije rezultate. Bez obzira na činjenicu da je Zakon predstavljao pozitivan pomak $\mathrm{u}$ domenu pravnog regulisanja zaštite konkurencije, danas je evidentno da je imao izražene nedostatke. Naime, kritike i negativne posledice neadekvatnih rešenja iz Zakona prevazilazile su benefite od njegove primene. Na udaru kritika bio je sam predmet Zakona. U članu 1 koji definiše predmet i cilj Zakona, navedeno je da se "uređuje zaštita konkurencije na tržištu radi obezbeđivanja ravnopravnosti učesnika na tržištu, a u cilju podsticanja ekonomske efikasnosti i ostvarivanja ekonomskog blagostanja društva u celini, naročito potrošača" (Zakon o zaštiti konkurencije, 2005). Prema mišljenju kritičara, $u$ ovom stavu postoji više nepreciznosti, i čak kontradikcija. Naime, cilj zakona treba da bude zaštita konkurencije, kao procesa čijim odvijanjem se postižu mnoge koristi za društvo, a ne zaštita postojećih konkurenata (ravnopravnost učesnika). Pored toga, najčešće su se nedostaci Zakona iz 2005. godine vezivali za: a) kaznene odredbe koje onemogućavaju ili makar značajno otežavaju delotvornu akciju protiv onih koji krše Zakon, pošto je Komisija za zaštitu konkurencije (Komisija) imala vrlo ograničena ovlašćenja da izriče kazne i praktično samo mogla da podnosi prekršajne prijave; b) neracionalno nisko postavljen prag godišnjeg prihoda koji dovodi do nastanka obaveze prijavljivanja koncentracije; c) položaj Komisije i garancije za njenu nezavisnost; d) izuzeća primene Zakona na lica koja se bave delatnošću od opšteg interesa (Skopljak, 2007, 66).

Funkcija koja je u potpunosti bila poverena Komisiji jeste odobravanje koncentracija na tržištu. Međutim, izuzetno nisko postavljen prag za prijavu koncentracije (godišnji prihod svih učesnika koncentracije veći od 10 miliona evra), doveo je do niza problema. $S$ obzirom na laku ostvarivost navedenog nivoa prihoda, ovakvo zakonsko definisanje praga dovelo je od preopterećenja Komisije zahtevima za odobravanje koncentracije. Na taj način je Komisiji ostavljeno malo prostora za usredsređivanje na značajnije slučajeve narušavanja slobodne konkurencije, zloupotrebu dominantnog položaja i restriktivne sporazume. Pored toga, kao nedostaci Zakona isticani su i dvosmislenost i nedovoljna preciznost $u$ definisanju samog dominantnog položaja, relevantnog tržišta i relevantnog geografskog tržišta. Konačno, Zakon 
je davao vladi velika diskreciona ovlašćenja $u$ propisivanju uslova, kriterijuma i odredaba kojima se reguliše svaka od relevantnih oblasti politike zaštite konkurencije. Kao rezultat prethodno pomenutog, posle relativno kratkog perioda pojavila se potreba izmene zakonske regulative, ali, takođe, i saznanje da takva promena sama po sebi nije dovoljna. Pored promene zakona, podjednako je važno usvajanje adekvatne metodologije za donošenje odluka o zaštiti konkurencije, u skladu sa praksom vodećih komisija u Evropi (Labus, 2008, 18).

Nakon Zakona iz 2005. godine usledilo je potpisivanje Sporazuma o stabilizaciji i pridruživanju (SSP) 2008. godine, kojim je zaštita konkurencije istaknuta kao jedna od značajnih obaveza Srbije u procesu integracije $\mathrm{u}$ EU (Sporazum o stabilizaciji i pridruživanju, 2008). U zavisnosti od toga na koji način se ugrožava konkurencija na jedinstvenom evropskom tržištu, komunitarno pravo konkurencije obuhvata nekoliko celina: restriktivna praksa i karteli, zloupotreba dominantnog položaja na tržištu i nadzor nad stvaranjem integracija, državna pomoć i državni monopoli (Spasić, 2007, 62). Sporazum o stabilizaciji i pridruživanju sadrži odredbe koje su blisko usklađene sa velikim delom zakonodavstva i intencija EU u oblasti zaštite konkurencije. Potpisivanjem Sporazuma, Srbija je prihvatila obavezu izgradnje institucija i usvajanja pravnog okvira kojim će biti obuhvaćene sve navedene oblasti komunitarnog prava konkurencije. $\mathrm{Na}$ ovaj način pitanje zaštite konkurencije u Srbiji dobilo je svoju međunarodnu dimenziju, s obzirom da domaća privreda i zbog veličine i zbog geografskog pozicioniranja ne može biti izuzeta iz globalnih tokova. Svaki restriktivni sporazum i svaka zloupotreba dominantnog položaja može imati prekogranični efekat, pa borba protiv monopolskog ponašanja u Srbiji više nije samo obaveza države prema njenim građanima, nego i njena međunarodna obaveza prema EU (GraićStepanović, 2007, 5). Svi zahtevi SSP u pogledu zaštite konkurencije, sa izuzetkom oblasti državne pomoći, već su bili obuhvaćeni Zakonom o zaštiti konkurencije i u tom smislu nisu predstavljali novinu. Novina je bila samo međunarodna kontrola i nadzor nad primenom utemeljenih pravila.

\section{Zaštita konkurencije u kontekstu Zakona iz 2009.}

Kao posledica neefikasnosti i nedovoljnih rezultata starog Zakona iz 2005. godine Srbija je 2009. godine usvojila novi Zakon o zaštiti konkurencije. Cilj je bio uklanjanje kritikovanih nedostataka zakona iz 2005. kako bi se konačno stvorili uslovi za fer tržišnu utakmicu koja će doprineti realizaciji unutrašnjih prioriteta zemlje $\mathrm{i}$ ispunjenju njenih međunarodnih obaveza. S obzirom da je novi Zakon kompatibilan sa preovlađujućim pravilima EU u domenu politike zaštite konkurencije, očekivanja su da će njegova primena obezbediti kvalitetniju ponudu robe i usluga građanima po povoljnijim cenama, i da ce dati doprinos integracionim procesima Srbije. Naglasak je na efikasnijem sankcionisanju povrede konkurencije, obezbeđivanju efikasnijeg načina sprečavanja zloupotrebe dominantnog položaja i nadzora nad stvaranjem integracija na tržištu. Zakon daje veća ovlašćenja Komisiji za zaštitu konkurencije, koja će moći efikasnije da dokazuje postojanje zloupotreba i kažnjava počinioce. Povećan je prag za obaveznu prijavu koncentracije na 20 miliona evra i u tom smislu su kapaciteti Komisije rasterećeni, kako bi bili stavljeni u službu sprečavanja ozbiljnijih slučajeva povrede konkurencije.

Posebni ciljevi koncepta Zakona mogu se sistematizovati na sledeći način: a) preciziranje i adekvatna transpozicija materijalnih pravila zaštite konkurencije koji se primenjuju u EU; b) smanjenje tereta administrativnih procedura za privredne subjekte $\mathrm{u}$ pogledu obaveze notifikacije, putem podizanja praga kontrole; c) stvaranje pravnoorganizacionih uslova za jačanje kapaciteta i proširenje procesnih ovlašćenja Komisije; d) davanje ovlašćenja Komisiji za primenu efikasnih i primenljivih mera u slučajevima povrede konkurencije; e) unapređenje procesno-pravnog režima (Graić-Stepanović, 2007, 6). Zakon obezbeđuje sistematičniji i smisleniji način određivanja osnovnih pravnih instituta i termina u oblasti zaštite konkurencije. Postupak kojim se određuje potencijalna povreda konkurencije se vodi na jedan celovit način pred Komisijom uz mogućnost participacije i saradnje svih zainteresovanih strana. 


\section{Ovlašćenja Komisije za zaštitu konkurencije}

Komisija za zaštitu konkurencije formirana je 2005. godine. Međutim, osnovi problemi zaštite konkurencije $\mathrm{u}$ Srbiji posle 2005. godine upravo se vezuju za neefikasno delovanje Komisije. Na udaru kritika je njena nedovoljna operativna i finansijska nezavisnost, s obzirom na to da se finansira iz budžeta države. Uz to, njene nadležnosti definisane Zakonom iz 2005. godine bile su nedovoljno jasne i ostavljale su široko diskreciono pravo vlade $\mathrm{u}$ ovom domenu. Kao jedan od problema ističe se ograničeni kapacitet Komisije i njena preopterećenost zahtevima za odobravanjem koncentracija, što je opet posledica neadekvatnog zakonskog regulisanja materije. Zakonom iz 2009. godine načinjeno je nekoliko bitnih izmena u domenu delovanja Komisije. Kada je u pitanju vršenje uviđaja, Zakon iz 2005. je predviđao saglasnost (izdavanje naloga) od strane nadležnih državnih organa za pregled službenih i drugih prostorija stranke. Zakon iz 2009. ne predviđa saglasnost nadležnih državnih organa i daje vrlo široka ovlašćenja prilikom vršenja uviđaja i predviđa i nenajavljeni uviđaj ukoliko se osnovano sumnja da postoji opasnost od uklanjanja ili izmene dokaza koji se nalaze kod stranke ili trećeg lica (čl. 52). Zakon iz 2005. je predviđao podnošenje predloga za određivanje privremenih mera od strane učesnika $u$ postupku, na osnovu koga je Komisija donosila rešenje o prestanku vršenja radnji povrede konkurencije i preduzimanju radnji kojima se otklanjaju njihove štetne posledice. Zakon iz 2009. ne predviđa podnošenje predloga za određivanje privremenih mera. Prema Zakonu iz 2005, Komisija za zaštitu konkurencije nije određivala upravne mere. Međutim, Zakon iz 2005, u čl. 57 predviđa i ovu nadležnost Komisije: "Ako Komisija utvrdi povredu konkurencije, odnosno drugu povredu ovog zakona, odrediće meru zaštite konkurencije, meru otklanjanja povrede konkurencije, odnosno drugu upravnu meru propisanu ovim zakonom" (Zakon o zaštiti konkurencije, 2009, 18).

U Zakonu iz 2009. definisane su dve vrste mera otklanjanja povrede konkurencije: mere ponašanja i strukturne mere. Rešenjem kojim se utvrđuje povreda konkurencije, Komisija može da odredi mere koje imaju za cilj otklanjanje utvrđene povrede konkurencije, odnosno, sprečavanje mogućnosti nastanka iste ili slične povrede, davanjem naloga za preduzimanje određenog ponašanja ili zabrane određenog ponašanja (mere ponašanja). Međutim, ukoliko se utvrdi značajna opasnost od ponavljanja iste ili slične povrede kao neposredne posledice same strukture učesnika na tržištu, Komisija može da odredi meru koja bi imala za cilj promenu u toj strukturi radi otklanjanja takve opasnosti, odnosno, uspostavljanje strukture koja je postojala pre nastupanja utvrđene povrede (strukturne mere). Zakon iz 2009, u čl. 70 predviđa i meru procesnog penala, po kome se učesniku na tržištu određuje mera plaćanja penala u iznosu od 500 evra do 5.000 evra za svaki dan ponašanja suprotno nalogu Komisije datom u postupku.

\section{Administrativni kapacitet Komisije za zaštitu konkurencije}

Bez obzira na nesumnjivi napredak $\mathrm{u}$ zakonskom regulisanju aktivnosti Komisije, njen institucionalni i administrativni kapacitet je potrebno i dalje unapređivati, a njeno osoblje kontinuirano usavršavati za delotvorno delovanje. Naglasak je potrebno staviti na razvijanje institucionalnog kapaciteta i obezbeđivanje stručnog kadra za ekonomsku analizu, u cilju pravovremenog detektovanja povrede konkurencije na tržištu. Pored toga, potrebno je praćenje rada sličnih tela u drugim zemljama, kako bi se učilo na iskustvima zemalja sa dobrom antimonopolskom praksom. Prema izveštaju iz 2010. godine nacionalna Komisija ima ukupno 29 zaposlenih. Na poslovima delokruga Komisije (rad na predmetima) radi 17 zaposlenih, 2 zaposlena su u Sektoru za domaću i međunarodnu saradnju, dok je 10 izvršilaca uposleno na zajedničkim poslovima za potrebe sektora koji se neposredno bave zaštitom konkurencije (Komisija za zaštitu konkurencije, 2011a, 8). Upoređivanjem broja zaposlenih u nacionalnoj komisiji i broja zaposlenih $\mathrm{u}$ telima za zaštitu konkurencije u zemljama članicama EU, generalni zaključak je da Srbija ima manji broj zaposlenih. Međutim, ovu komparaciju treba posmatrati uslovno, s obzirom da pojedina nacionalna tela za zaštitu konkurencije obavljaju i poslove zaštite potrošača, državne pomoći ili kontrole javnih nabavki. Na Grafikonu 1 prikazan je komparativni pregled broja zaposlenih u telima za zaštitu konkurencije u Srbiji i zemljama u okruženju u 2010. godini ukupno i na poslovima delokruga komisije (rad na predmetima). 


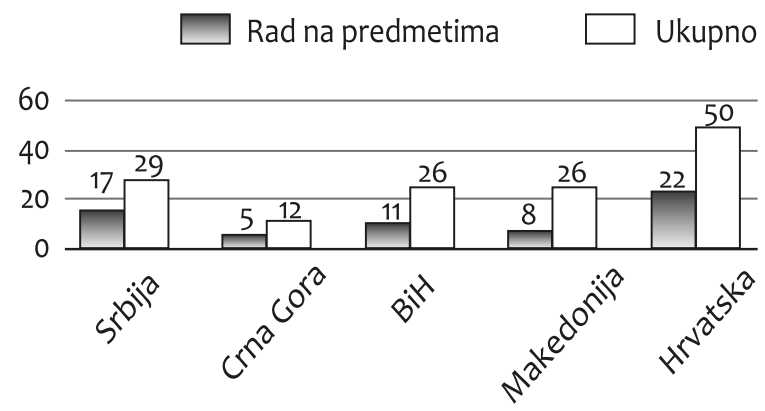

Grafikon 1 Broj zaposlenih u telima za zaštitu konkurencije (2010)

Izvor: Ganon \& Petaković, 2011, 94

U poređenju sa zemljama u okruženju, Srbija ima veći broj zaposlenih kako ukupno, tako i na predmetima od većine zemalja. Veći broj zaposlenih postoji jedino u Hrvatskom telu za zaštitu konkurencije, ali je to zemlja u okruženju sa najboljom antimonopolskom praksom.

Od konstituisanja Komisije za zaštitu konkurencije 2005. godine, pretežna delatnost bila je odobravanje koncentracija. Značajniji oblici narušavanja konkurencije na tržištu, zloupotreba dominantnog položaja i restriktivni sporazumi bili su daleko manje zastupljeni u praksi rada Komisije. U Tabeli 3 dat je pregled predmeta nacionalne komisije za zaštitu konkurencije u periodu od 2006. do 2010. godine.

Tek u 2010. godini dolazi do smanjenja zahteva za odobravanjem koncentracija. To je posledica donošenja Zakona u 2009, kojim je povećan prag ukupnog godišnjeg prihoda koji predstavlja uslov za obaveznu prijavu koncentracija (Zakon iz 2005. bio je postavljen na nerealno niskom nivou). Međutim, nije zabeleženo povećanje broja predmeta $\mathrm{u}$ kojima se razmatra zloupotreba dominantnog položaja i restriktivni sporazumi između učesnika na tržištu. Na Grafikonu 2 dat je uporedni pregled broja prijava koncentracije $\mathrm{u}$ Srbiji i zemljama iz okruženja.

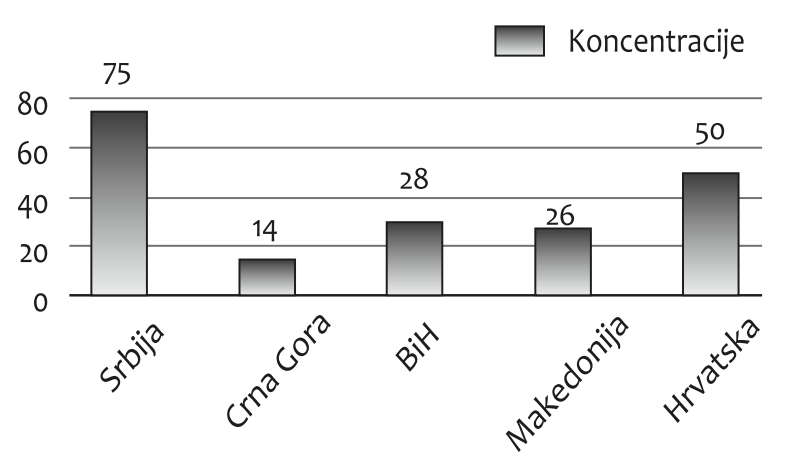

Grafikon 2 Broj prijava koncentracija u Srbiji i zemljama u okruženju (2010)

Izvor: Ganon \& Petaković, 2011, 96

Bez obzira na nesumnjivo smanjenje broja prijava koncentracija Komisiji u 2010. godini, Srbija je i dalje zemlja sa najvećim brojem prijava u komparaciji sa zemljama u regionu. Intencija Zakona iz 2009. da se kapaciteti Komisije rasterete i stave u funkciju kontrole i sankcionisanja ozbilinijih poremećaja na tržištu nije dovela do ozbiljnijih pozitivnih pomaka.

Tabela 3 Pregled predmeta Komisije za zaštitu konkurencije u Srbiji (2006 - 2010)

\begin{tabular}{lccccc}
\hline & 2006 & 2007 & 2008 & 2009 & 2010 \\
\cline { 2 - 6 } Restriktivni sporazumi & 1 & 4 & 20 & 16 & 9 \\
Izuzeće sporazuma od zabrane & 1 & 4 & 8 & 7 & 5 \\
Zloupotreba dominantnog položaja & 10 & 13 & 2 & 19 & 6 \\
Koncentracije učesnika na tržištu & 47 & 125 & 137 & 116 & 75 \\
Ukupno & 58 & 146 & 167 & 158 & 95 \\
\hline
\end{tabular}

Izvor: Godišnji izveštaji o radu Komisije za zaštitu konkurencije, 2006 - 2010. 


\section{Posledice neadekvatnog institucionalnog kapaciteta}

$\mathrm{Na}$ osnovu dosadašnje analize regulatornog okvira, institucionalnog i administrativnog kapaciteta Komisije, jasno je da se zaštiti konkurencije u Srbiji ne pridaje odgovarajući značaj. Zbog toga srpski ekonomski sistem nikako nije tržišan u standardnom smislu. Zakoni su (bili) obično loši i često se nisu primenjivali, a država i politika su neformalnim putem preuzele ulogu svemoćnog arbitra koji odlučujuće utiče na sve ekonomske tokove.

Uplitanje politike $\mathrm{u}$ ovu oblast generisalo je česta razmimoilaženja u stavovima $i$ analizama stručnih $i$ nepristrasnih krugova, pa čak i predstavnika tela za zaštitu konkurencije. Kad se te razlike u stavovima pokažu kao posebno velike, narasta sumnja u dobijene istraživačke nalaze, pa čak i u zakonsku zasnovanost određenog postupka. Među njima je i postupak koji je Komisija vodila protiv kompanije Danube Foods Group (Komisija za zaštitu konkurencije, 2008, Komisija za zaštitu konkurencije, 2011b) ili pokušaja zabrane kupovine Hellenic Sugar od strane kompanije Sunoko (Stojanović \& Radivojević, 2011, 480-484; Komisija za zaštitu konkurencije, 2012).

Jedna od ilustracija stanja konkurencije na tržištima u Srbiji je nedavno usvojena Uredba o ograničenju marži na osnovne životne namirnice (Uredba o posebnim uslovima prometa određene robe, 2011). Da je na ovom tržištu postojao viši novo konkurencije, marže bi se kretale u normalnim okvirima, pa bi donošenje Uredbe bilo nepotrebno. Ovako je država svojom intervencionističkom merom indirektno uticala na formiranje cena $u$ maloprodaji, što ukazuje na činjenicu da ona nije (bila) u stanju da instrumentima politike zaštite konkurencije uspostavi delotvornu konkurenciju na ovom tržištu. Takođe, navedena Uredba je imala negativan uticaj na male trgovce (tzv. prodavnice u komšiluku), čije poslovanje u najvećoj meri zavisi upravo od marži na osnovne životne namirnice. Ograničavanjem marži na ove proizvode, veliki broj takvih prodavnica je prinuđen da obustavi svoje poslovanje ili da posluje sa značajnim gubitkom. Prema podacima Unije poslodavaca Srbije, $u$ periodu od 1. januara (kada je Uredba stupila na snagu) do 15. februara 2012. godine zatvoreno je 875 malih trgovina, a 3.430 ljudi je izgubilo posao.
Sasvim opravdano se može postaviti pitanje šta je sa maržama na proizvode koji se ne svrstavaju u osnovne životne namirnice. S obzirom da se takvi proizvodi ne koriste za zadovoljavanje osnovnih životnih potreba, oni se mogu svrstati u grupu više ili manje luksuznih dobara, te je sasvim razumna sumnja da marže na neke od ovih proizvoda premašuju $50 \%$.

\section{ZAKLJUČAK}

Bilo da je u pitanju neadekvatna zakonska regulativa, nedovoljan institucionalni kapacitet ili politički pritisak, stiče se utisak da se politika zaštite konkurencije u Srbiji svodi na politiku zaštite monopola od konkurenata. U odsustvu celovite i koherentne, dugoročne i harmonizovane strategije institucionalnih reformi može doći do međusobnog preklapanja, pa čak i sukobljavanja pojedinih institucionalnih zahvata, rasipanja stručnih resursa, novca i vremena, kao i povećanja drugih disfunkcionalnih troškova.

Ovde se ne pledira za rigidno shvaćenu i centralizovanu plansku opciju reformi, već za osmišljene i koordinirane reformske zahvate, koji će podići procese institucionalizacije na nivo utvrđenih evropskih standarda, sa osnovnim ciljem da se postojeći institucionalni deficit smanji.

Stvorena tranziciona recesija nastala je kao posledica restrukturiranja privrede i prilagođavanja novim uslovima poslovanja bez sinhronizovanih promena institucija. Uz to, čini se da nije postignut politički konsenzus oko neophodnosti radikalnih zahvata $\mathrm{u}$ zaštiti konkurencije. $\mathrm{S}$ obzirom na zakašnjenje $\mathrm{u}$ stvaranju pravne osnove i odgovarajućih institucija, neophodno je kontinuirano unapređivanje regulacije ove značajne oblasti. To je jedan od preduslova za temeljnu rekonstrukciju privrede i društva. Bez neophodnosti napuštanja strategijskih opredeljenja, kreatori tranzicionih procesa u Srbiji treba da vrše dopune i korekcije u koncipiranju ili implementaciji privredno-sistemskih rešenja kako bi se otklonio nesklad između normi i faktičkog stanja, a time i sprečilo kompromitovanje već postignutih rezultata. Polazeći od loših performansi naše privrede $\mathrm{i}$ neefikasnosti institucija, $u$ radu su upućene jasne kritike dosadašnjem tranzicionom inženjeringu $u$ 
oblasti zaštite konkurencije. Time je stvorena osnova za dalje istraživanje i identifikaciju uzroka, opisivanje karakteristika i ustanovljavanje tendencija u razvoju ove važne oblasti ekonomske politike.

\section{REFERENCE}

European Bank for Reconstruction and Development (EBRD) (2011). Transition Report 2011 - Crisis and Transition: The People's Perspective, http://www.ebrd.com/

Ganon, P., \& Petaković, R. (2011). U fokusu: Konkurencija. Beograd, Srbija: AOD Karanović i Nikolić.

Graić-Stepanović, S. (2009). Efekti pristupanja Srbije Evropskoj uniji - politika konkurencije. Konkurencija. Beograd, Srbija: Fakultet za ekonomiju, finansije i administraciju.

Jones, A., \& Sufrin, B. (2001). EC Competition Law. Oxford, UK: Oxford University Press.

Комисија за заштиту конкуренције Републике Србије. (2008). Pemerbe od 25. jануара 2008.

Комисија за заштиту конкуренције Републике Србије. (2011а). Годишть извештај о раду Комисије за заштиту конкуренције за 2010.

Комисија за заштиту конкуренције Републике Србије. (2011b). Решенье бр. 5/0-02-43/2011. од 24. јануара 2011.

Комисија за заштиту конкуренције Републике Србије. (2012). Решенье бр. 6/0-02-18/2012-3. од 19. јануара 2012.

Labus, M. (2008). Analiza tržišne koncentracije: Primer C / C market. Beograd, Srbija: Belox Advisory Services.
Ristić, B. (2010). Sprovođenje antimonopolske politike u Srbiji: dosadašnja iskustva i preporuke. Kvartalni monitor, 19, 6880 .

Skopljak, Z. (2007). Godinu dana rada Komisije za zaštitu konkurencije. Kvartalni monitor, 8.

Spasić, I. (2007). Komunitarno pravo konkurencije. Strani pravni život, (1-2)

Споразум о стабилизацији и придруживаюу. (2008). Службени гласник Републике Србије, 83.

Stojanović, B. (2003). Tržište Evropske unije - konkurencija $i$ trgovinska politika. Niš, Srbija: Ekonomski fakultet Univerziteta u Nišu.

Stojanović, B., \& Radivojević, V. (2010). Koncentracija ponude kao izraz nesavršenosti tržišta: Primer nespecijalizovane trgovine na malo na tržištu grada Niša. Ekonomika preduzeća, 58(7), 327-338.

Stojanović, B., \& Radivojević, V. (2011). Economic Glance at Antitrust Legislation in Serbia and Others Western Balkan Countries: Case Study - Dairy Products Market. Journal for Bussines and Economics, 2(6), 472-487.

Влада Републике Србије (2011). Уредба о посебним условима промета одређене робе. Службени гласник Републике Србије, 102.

World Economic Forum. (2011). Global Competitiveness Report 2011-2012. http://www.weforum.org/

Закон о заштити конкуренцчије. (2005). Службени гласник Републике Србије, 79.

Закон о заштити конкуренцчије. (2009). Службени гласник Републике Србије, 51.
Primljeno 2. jula 2012, nakon revizije, prihvaćeno za publikovanje 9. jula 2012. 
Boban Stojanović je redovni profesor Ekonomskog fakulteta Univerziteta u Nišu. Doktorirao na Ekonomskom fakultetu Univerziteta u Beogradu. Oblasti naučnog interesovanja su: monopoli, zaštita konkurencije, tržište Evropske unije. Član je redakcije časopisa Journal of business and economics i Panoeconomicus.

Vladimir Radivojević je student doktorskih studija na Ekonomskom fakultetu Univerziteta u Nišu. Polja interesovanja su: analiza tržišta, nesavršene tržišne strukture, zaštita konkurencije.

Tanja Stanišić je student doktorskih studija na Ekonomskom fakultetu Univerziteta u Nišu. Saradnik je na Projektu osnovnih istraživanja (broj 179066), koje finansira Ministarstvo nauke Republike Srbije. 